\title{
Siluro-Devonian tectonostratigraphic relationships in the Portage Brook area, northern New Brunswick: implications for timing of deformational events in the Bathurst Mining Camp
}

\author{
S.J. Gower and S.R. McCutcheon \\ Geological Surveys Branch, New Brunswick Department of Natural Resources and Energy, \\ P.O. Box 50, Bathurst, New Brunswick E2A 3Z1, Canada
}

Date Received April 9, 1996

Date Accepted October 9, 1996

\begin{abstract}
In the Portage Brook area, Siluro-Devonian rocks of the Chaleurs Bay Synclinorium are juxtaposed against polydeformed Cambro-Ordovician rocks of the Bathurst Mining Camp along the northerly trending Portage Brook Fault. Rocks of the Chaleurs Group have been identified for the first time west of the Portage Brook Fault, and are subdivided into four lithological units: conglomerate, sandstone and siltstone of the Simpsons Field Formation; mafic volcanic rocks of the Bryant Point Formation; felsic volcanic rocks of the Benjamin Formation; and thickly bedded, brownish grey to reddish grey sandstone of the Greys Gulch Formation. The presence of two pre-depositional cleavages in Ordovician pebbles in the middle Wenlockian to late Ludlovian Simpsons Field Formation indicates that $\mathrm{D}_{2}$ deformation in the Bathurst Mining Camp started prior to the Late Silurian, i.e., earlier than considered by some workers. This observation is supported by the truncation of at least two strong fabrics in Cambro-Ordovician rocks by Late Silurian/Early Devonian mafic intrusions. An alkali granite (radiometrically dated at $414+11 /-1 \mathrm{Ma}$ ) clearly intruded, and altered to hornfels, clastic rocks of the Simpsons Field Formation. The granite appears to grade laterally into and to be coeval with volcanic rocks of the Benjamin Formation, thus suggesting that the age of the intrusion is close to the lower error limit.
\end{abstract}

Dans le secteur du ruisseau Portage, des roches siluro-dévoniennes du synclinorium de la baie des Chaleurs sont juxtaposées contre des roches polydéformées cambro-ordoviciennes du Camp minier de Bathurst le long de la ligne d'orientation vers le nord de la faille du ruisseau Portage. On a pour la première fois repéré des roches du groupe de Chaleurs à l'ouest de la faille du ruisseau Portage. Celles-ci se subdivisent en quatre unités lithologiques : le conglomérat, le grès et le siltstone de la Formation de Simpsons Field; les roches volcanomafiques de la Formation de Bryant Point et les roches volcanofelsiques de la Formation de Benjamin; ainsi que le grès allant du gris brunâtre au gris rougeâtre en couches épaisses de la Formation de Greys Gulch. La présence de deux schistosités antérieures à la sédimentation dans des galets de l'Ordovicien de la Formation du Wenlock moyen au Ludlovien tardif de Simpsons Field révèle que la déformation D2 à l'intérieur du Camp minier de Bathurst a débuté avant le Silurien supérieur, c.-à-d. plus tôt que le pensaient certains chercheurs. La truncature d'au moins deux structures dans des roches cambro-ordoviciennes d'intrusions mafiques du Silurien supérieur au Dévonien inférieur appuie cette observation. Du granite alcalin (situé à $414+11 /-1$ Ma par datation radiométrique) a nettement circonscrit et transformé en hornfels des roches clastiques de la Formation de Simpsons Field. Le granite semble se fondre latéralement dans des roches volcaniques de la Formation de Benjamin auxquelles il semble contemporain, ce qui laisse supposer que l'intrusion est d'un âge proche de la limite d'erreur inférieure.

[Traduit par la rédaction]

\section{INTRODUCTION}

It is now generally accepted that the polyphase deformational history of the rocks in the Bathurst Mining Camp, located in the northern part of the Miramichi Anticlinorium (Fig. 1), records Late Ordovician to Late Silurian closure of a back-arc basin and collision between Laurentia and the Gander margin of Gondwana (van Staal, 1994). However, the timing of the deformational events $\left(D_{1}\right.$ to $\left.D_{4}\right)$ in the Camp and the relationship of these events to the sedimentary and tectonic evolution of the Chaleurs Bay Synclinorium are not clearly understood. Geological relationships defined during regional mapping in 1995 in the Portage Brook area (NTS $21 \mathrm{O} / 7 \mathrm{~h}$ and southern part of $21 \mathrm{O} / 10 \mathrm{a}$, Fig. 1) place important constraints on the timing of these deformational events. Field relationships, supported by geochemistry and recently released radiometric dates from intrusions in the Portage Brook area (Whalen, 1993) suggest that the $D_{2}$ deformation in the Bathurst Mining Camp started prior to the Late Silurian, contrary to some interpretations. In addition, structures found in the Chaleurs Bay Synclinorium most likely correlate with the latest stage of deformation in the Bathurst Mining Camp.

The purpose of this paper is to: (1) describe the geological setting of the Portage Brook area, in particular to document the presence of rocks of the Chaleurs Group west of the Portage Brook Fault; (2) present evidence suggesting that $\mathrm{D}_{2}$ deformation in the Bathurst Mining Camp occurred prior to the Late Silurian; and (3) briefly discuss some implications for the tectonic evolution of northern New Brunswick. 


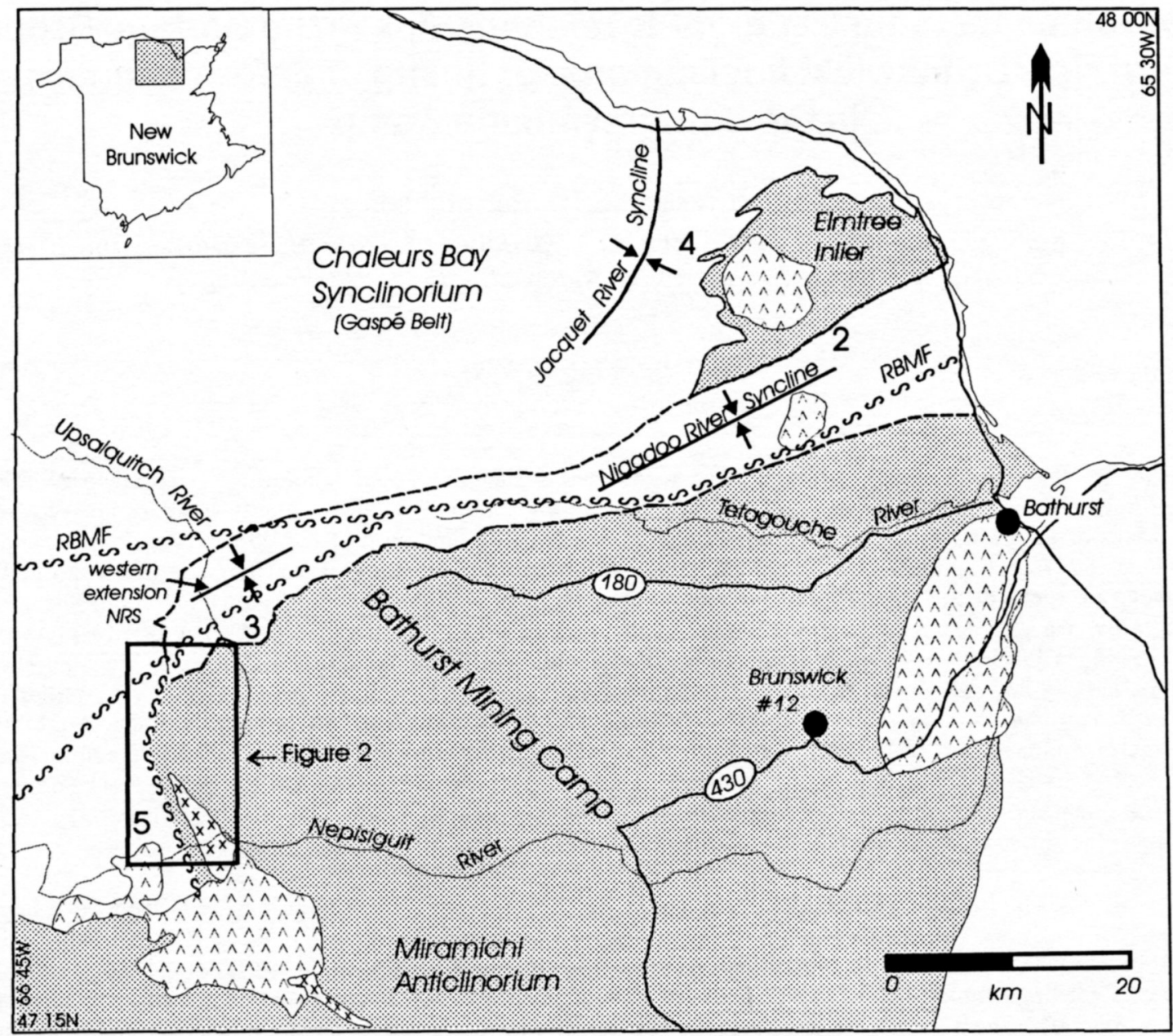

Fig. 1. Location map showing the position of the Portage Brook area (inset) with respect to the Bathurst Mining Camp, New Brunswick. Numbers 2, 3, 4 and 5 refer to locations of stratigraphic columns shown in Figure 3. Shaded area indicates the Miramichi terrane; inverted $v$ pattern indicates felsic intrusions; $x$ pattern indicates gabbro; $R B M F=$ Rocky Book - Millstream Fault.

\section{Geological Setting}

Paleozoic rocks in northeastern New Brunswick belong to three major structural divisions, the Chaleurs Bay Synclinorium, the Miramichi Anticlinorium and the Elmtree Inlier (Fig. 1). The Elmtree Inlier and Miramichi Anticlinorium (Rodgers, 1970) comprise Cambro-Ordovician rocks of the Gander and Dunnage zones. The Gander Zone represents a Lower Paleozoic west-facing continental margin and the Dunnage Zone is largely a subduction complex formed during closure of a back-arc basin (van Staal and Fyffe, 1991). The Chaleurs Bay Synclinorium is one of three structural divisions that make up the Gaspé Belt, a broad depositional belt that extends from Maine through northern New Brunswick and into the Gaspé Peninsula (Malo and Bourque, 1993). The Gaspé Belt is interpreted as a successor basin deposited on Cambro-Ordovician basement after the Taconian Orogeny (Malo and Bourque, 1993). The Chaleurs Bay Synclinorium corresponds in part to the Matapedia Cover Sequence of Fyffe and Fricker (1987). The contact between the Chaleurs Bay Synclinorium and the older Miramichi Anticlinorium and Elmtree Inlier is either a fault or an unconformity (Helmstaedt, 1971; Fyffe and Noble, 1985). The Miramichi Anticlinorium has been divided into three groups of rocks: (1) Cambro-
Ordovician clastic rocks of the Miramichi Group, (2) volcanic and sedimentary rocks of the Middle to Upper Ordovician Tetagouche Group, and (3) volcanic rocks of the Lower to Upper Ordovician Fournier Group. The Elmtree Inlier contains rocks of the Tetagouche and Fournier groups and is considered to be a northeastern extension of the Miramichi Anticlinorium.

In the Portage Brook area (Fig. 2), the Miramichi Group has been subdivided into three formations following the stratigraphic framework defined in the eastern part of the Camp: (1) thickly-bedded quartzite of the Chain of Rocks Formation, (2) thin- to medium-bedded quartzites interbedded with greenish grey to dark grey slate of the Knights Brook Formation, and (3) thin-bedded, dark grey to black slate and siltstone locally interlayered with quartzo-feldspathic wacke of the Patrick Brook Formation. The conformably overlying Tetagouche Group comprises quartz-feldspar phyric volcaniclastic rocks of the Nepisiguit Falls Formation, mainly feldspar-phyric lithic tuff of the newly defined Mount Brittain Formation (Gower, in press) and alkali basalt and sedimentary rocks of the Boucher Brook Formation. The Fournier Group is represented by mafic volcanic rocks of the Sormany Formation and is restricted to a small tectonically emplaced sliver near the northeastern corner of the map (Fig. 2). 


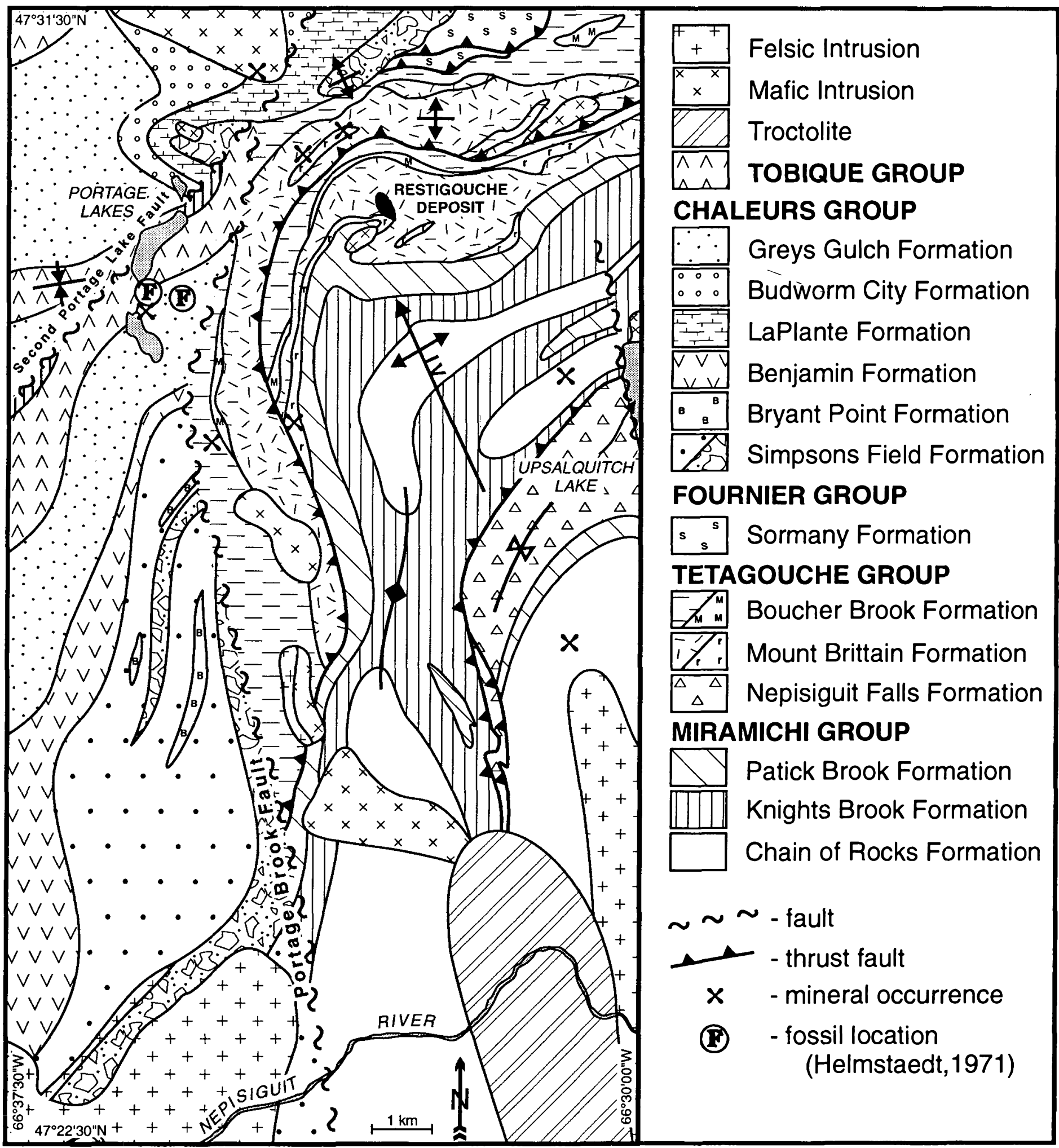

Fig. 2. Simplified geological map of the Portage Brook area (NTS $21 \mathrm{O} / 7 \mathrm{~h}$ and part of $21 \mathrm{O} / 10 \mathrm{a}$ ). Lithological descriptions of formations are given in text. Mount Brittain volcanics: $r=$ aphyric felsic volcanic rocks; random dashes = mainly feldspar phyric volcanic rocks. Boucher Brook Formation: dashes $=$ sedimentary rocks, $M=$ mafic volcanic rocks. Simpsons Field Formation: dots $=$ fine grained clastic rocks; circles $=$ conglomerate .

In northeastern New Brunswick, the Chaleurs Bay Synclinorium is transected by a major dextral strike-slip fault, the Rocky Brook-Millstream Fault (RBMF). North of the RBMF (Fig. 2), the Chaleurs Bay Synclinorium contains
Silurian to Lower Devonian sedimentary and volcanic rocks of the Chaleurs Group and Lower Devonian sedimentary and volcanic rocks of the Dalhousie Group.

The Nigadoo River Syncline (Fig. 1) is a belt of Sil- 
urian to Lower Devonian sedimentary rocks belonging to the Chaleurs Group, which separates the Elmtree Inlier and Miramichi Anticlinorium. This syncline represents a sedimentary basin that developed in association with movement along the RBMF.

\section{STRATIGRAPHIC RELATIONSHIPS}

\section{in the Chaleurs Bay Synclinorium}

At the type locality, along the northern side of Chaleurs Bay, Quebec, the Chaleurs Group consists of three lithological assemblages: (1) a lower, fine to coarse grained, siliciclastic assemblage (Clemville, Weir and Anse Cascon formations); (2) a distinctive middle limestone assemblage (Anse à PierreLoiselle and $\mathrm{La}$ Vieille formations); and (3) an upper fine grained siliciclastic assemblage (Gascons and Indian Point formations) with intervening reef limestones and red beds (West Point Formation) and subaerial mafic volcanic rocks (Black Cape Volcanics) (Malo and Bourque, 1993; Fig. 3). A detailed description of the type section is given in Bourque (1987) and summarized in Bourque et al. (1995). Fossil occurrences and similar lithologies have permitted correlation with New Brunswick, although some stratigraphic names differ on opposite sides of Chaleurs Bay (Bourque et al., 1995).

Early studies of the stratigraphy of the Chaleurs Group in New Brunswick include Alcock (1935), Greiner (1967), Noble (1976), Fyffe and Noble (1985) and Irrinki (1990), as summarized in Bourque et al. (1995). Recent mapping in northern New Brunswick was done by Walker and McCutcheon (1995), and five structural/depositional belts in the Chaleurs Bay Synclinorium are now recognized. Using the nomenclature of Walker and McCutcheon (1995), three sections that are key to correlations made in the Portage Brook area, are reviewed, one section in the Nigadoo River Syncline north of the RBMF, a second section in the Nigadoo River Syncline south of the RBMF, and a third section along Antinouri Lake Stream (Jacquet River Syncline).

In the northern part of the Nigadoo River Syncline (Fig. 1), the lower part of the Chaleurs Group consists of a coarse grained siliciclastic assemblage (Weir Formation) and a limestone unit (La Vieille Formation). Lithological similarities and paleontological data from the limestone have allowed direct correlation with the type Chaleurs Group in the Gaspé and the same formation names are applied (Walker and McCutcheon, 1995). The upper part of the Chaleurs Group in this area consists of conglomerate and sandstone of the Simpsons Field Formation, calcareous siltstone and limestone of the La Plante Formation, and fine grained clastic rocks of the Free Grant Formation, in ascending order. Notably, volcanic rocks are absent (Walker and McCutcheon, 1995). The Simpsons Field Formation conformably overlies the Llandoverian to lower Wenlockian LaVieille Formation and is overlain by the LaPlante Formation that has yielded conodonts of Pridolian to Early Devonian age. The age of the Simpsons Field Formation is, therefore, constrained between the middle Wenlockian to late Ludlovian (Walker and McCutcheon, 1995). The La Plante Formation is con- sidered to be coeval with the West Point Formation in the type Chaleurs Group (Fig. 3).

In the western extension of the Nigadoo River Syncline (Fig. 1, south of the RBMF), the Chaleurs Group comprises sedimentary rocks of the Simpsons Field, LaPlante, Budworm City and Greys Gulch formations (Fig. 3). All of these formation names, except the LaPlante Formation, were introduced by Walker and McCutcheon (1990). The Budworm City Formation comprises grey, bluish-grey to black siltstone, sandstone and minor limestone, whereas the Greys Gulch Formation contains greyish-red and greenish grey siltstone and sandstone. The Greys Gulch Formation constitutes the top of the Chaleurs Group in this area and is conformably and gradationally overlain by rocks of the Tobique Group. The Greys Gulch Formation is considered to be equivalent to red beds found in the upper part of the West Point Formation (Walker and McCutcheon, 1995).

West of the Elmtree Inlier, in the eastern part of the Jacquet River Syncline, the lower part of the Chaleurs Group unconformably overlies sedimentary rocks of the Tetagouche Group, and includes the Weir and LaVielle formations, although the Weir Formation is absent in many places. In contrast to the predominately sedimentary sections in the Nigadoo River Syncline and at the type section in Gaspé, the upper part of the Chaleurs Group in this area contains upper Wenlockian to Ludlovian volcanic rocks of the South Charlo, Bryant Point and Benjamin formations. The South Charlo Formation (introduced by Irrinki, 1990) mainly consists of pebble to boulder conglomerate, that is characterized by an abundance of mafic volcanic clasts. The Bryant Point Formation (introduced by Greiner, 1967) predominately consists of mafic volcanic flows interbedded with lesser amounts of pebble conglomerate. The Bryant Point and South Charlo formations are considered to be laterally equivalent to upper Wenlockian to Ludlovian sedimentary rocks of the Simpsons Field Formation in the Nigadoo River Syncline (Walker and McCutcheon, 1995). The Benjamin Formation, a name introduced by Greiner (1967), is a unit of felsic volcanic rocks found in the Chaleurs Bay Synclinorium west of the Elmtree Inlier. In the Jacquet River area these volcanic rocks have yielded a U-Pb zircon age of $423 \pm 3 \mathrm{Ma}$ (Walker and McCutcheon, 1995) confirming Greiner's suggested age assignment. The Benjamin Formation conformably overlies the Bryant Point Formation and is disconformably overlain by the Dalhousie Group.

\section{Geology of the Portage Brook area}

In the Portage Brook map area (Fig. 2) a northerly trending fault, the Portage Brook Fault, separates the Cambro-Ordovician rocks of the Miramichi Anticlinorium in the east of the area from Siluro-Devonian rocks of the Chaleurs Bay Synclinorium to the west (Fig. 2). In the northern part, mostly north of Second Portage Lake Fault, Siluro-Devonian rocks occupy a syncline, the western extension of the Nigadoo River Syncline. One of the reference sections (3 in Fig. 3 ) is from this area.

West of the Portage Brook Fault and south of the Sec- 
1
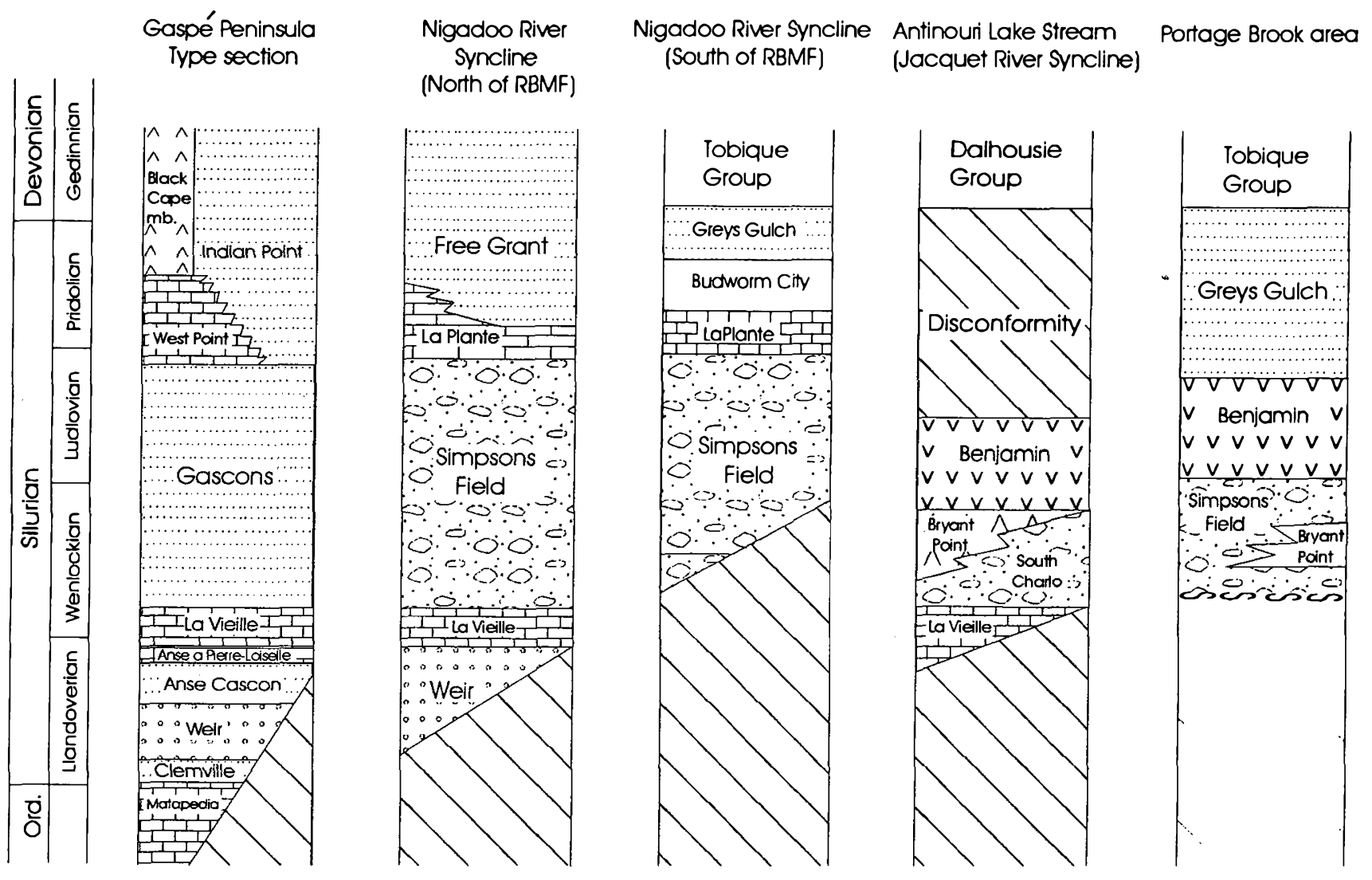

2
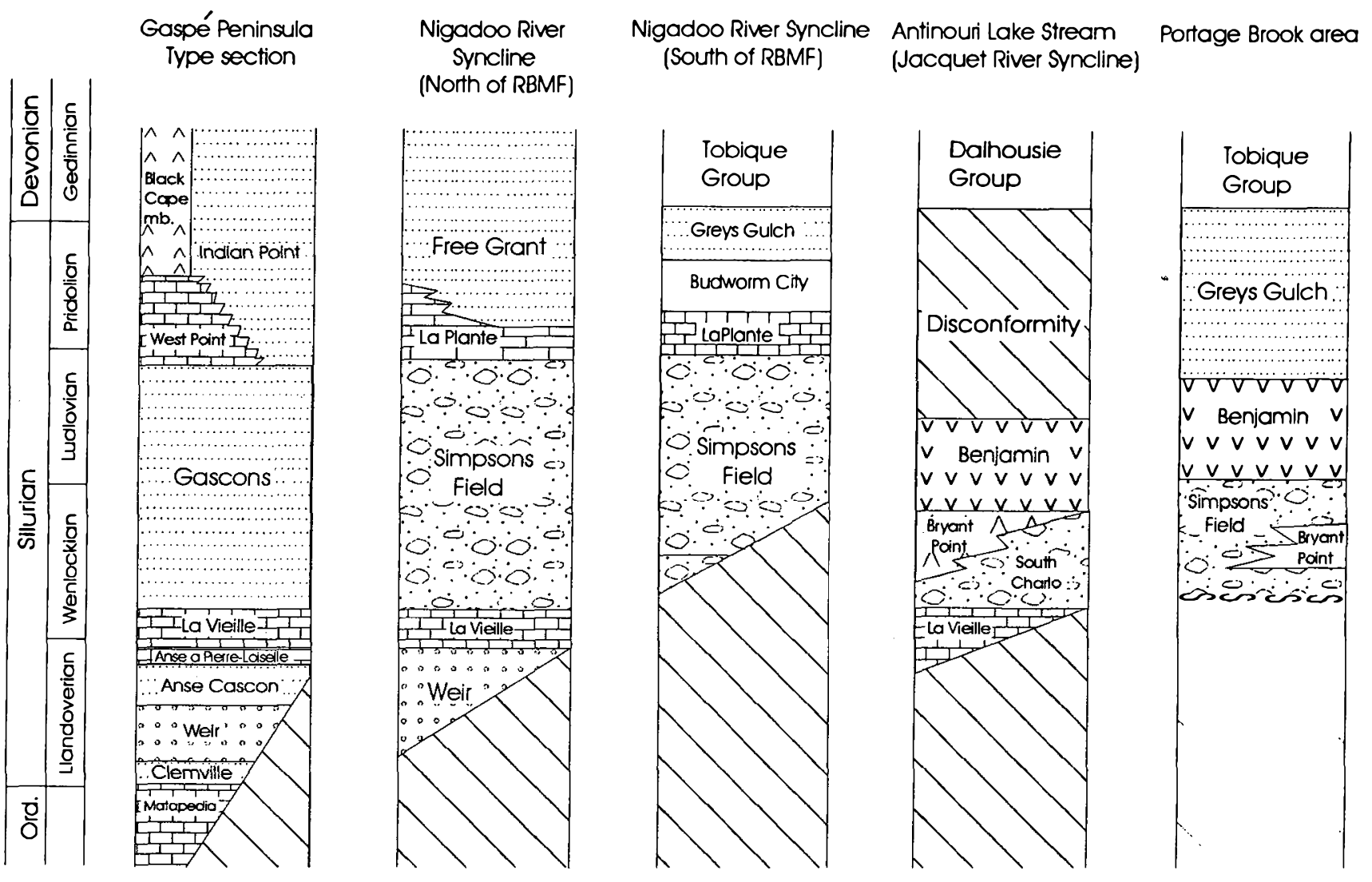

3

Nigadoo River Syncline (South of RBMF)

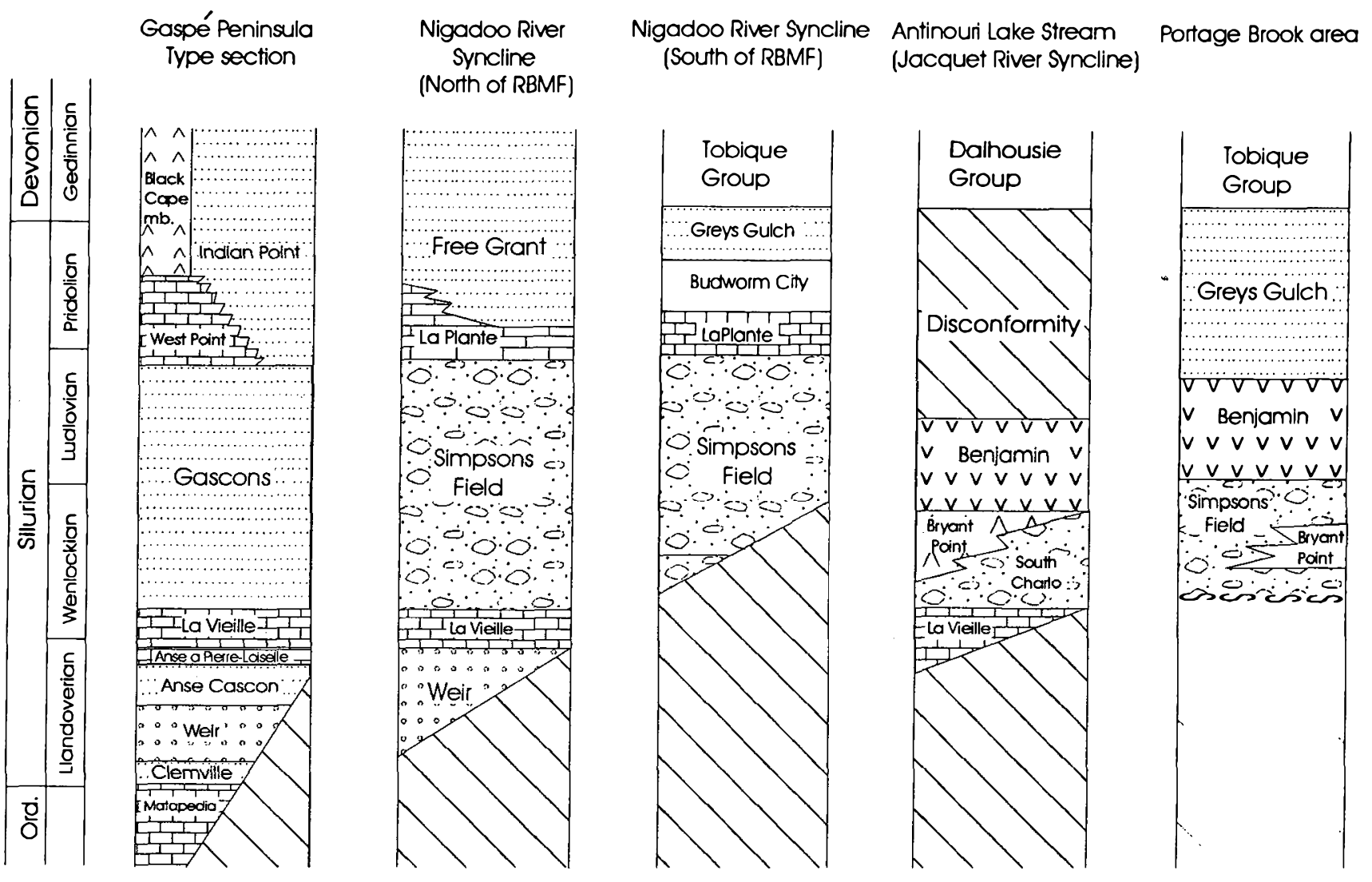

4

5

Fig. 3. Stratigraphic columns of the Chaleurs Group from: (1) the Gaspé type section Bourque (1987), different parts of northern New Brunswick; (2) Nigadoo River Syncline north or the RBMF; (3) Nigadoo River Syncline south of the RBMF; (4) Antinouri Stream section in the Jacquet River Syncline from Walker and McCutcheon (1995); and (5) the section west of the Portage Brook Fault. Columns 2 to 5 are located on Figure 1. See text for unit descriptions. Diagonal lines indicate missing section.

ond Portage Lake Fault, the Chaleurs Bay Synclinorium consists of a thick, northeast-striking homoclinal sequence of sedimentary and volcanic rocks that were all considered to be Lower Devonian, largely based on fossils found in calcareous sandstone east of Portage Lakes (Helmstaedt, 1971; Fig. 2). However, strata found south of, i.e., stratigraphically below, this fossil location and truncated at the Portage Brook Fault have been re-assigned to the Silurian based on lithological correlation with the Chaleurs Group. These rocks are briefly described below.

\section{Chaleurs Group}

A thick clastic unit consisting of sandstone, siltstone and polymictic conglomerate and occurring at the apparent base of the section west of the Portage Brook Fault and south of the Second Portage Lake Fault (Fig. 2), is correlated with the Simpsons Field Formation because: (1) it exhibits similar bedding style and composition to the Simpsons Field type area; (2) it has been intruded and altered to hornfels by alkali granite of the Late Silurian-Early Devonian Mount Elizabeth Intrusive Complex and, therefore, cannot be part of the Lower Devonian Tobique Group; and (3) it is overlain by a sequence of volcanic and sedimentary rocks that are lithologically similar to the upper part of the Chaleurs Group in the Jacquet River Syncline. Thick beds of polymictic conglomerate, with clasts ranging up to $20 \mathrm{~cm}$ in diameter, predominate in the lower part of this unit, but fine upward to thinly bedded sandstone and siltstone. Clasts are well rounded and include chert, jasper, quartz, sandstone, slate, mafic and felsic volcanic rocks, gabbro and granite. Helmstaedt (1971) noted that these conglomerates contain Ordovician pebbles with two pre-depositional cleavages. Thin sections from conglomerate of the Simpsons Field Formation (Fig. 4) confirm the presence of both a planar fabric and a crenulation cleavage in sedimentary and gabbroic pebbles.

Porphyritic and amydaloidal mafic volcanic rocks that are interlayered with these conglomerates and sandstones are assigned to the Bryant Point Formation. In the field area mafic lavas are typically dark-grey, feldspar-porphyritic and vesicular. Feldspar phenocrysts are generally 1 to $2 \mathrm{~mm}$ in size.

A belt of felsic volcanic rocks overlies the Simpsons Field Formation in the Portage Brook area. These volcanic rocks occupy the same statigraphic position (i.e., conformably above conglomerate) as the felsic volcanic rocks in the Jacquet River Syncline and therefore have been assigned to the Benjamin Formation. In the Portage Brook area, the felsic 

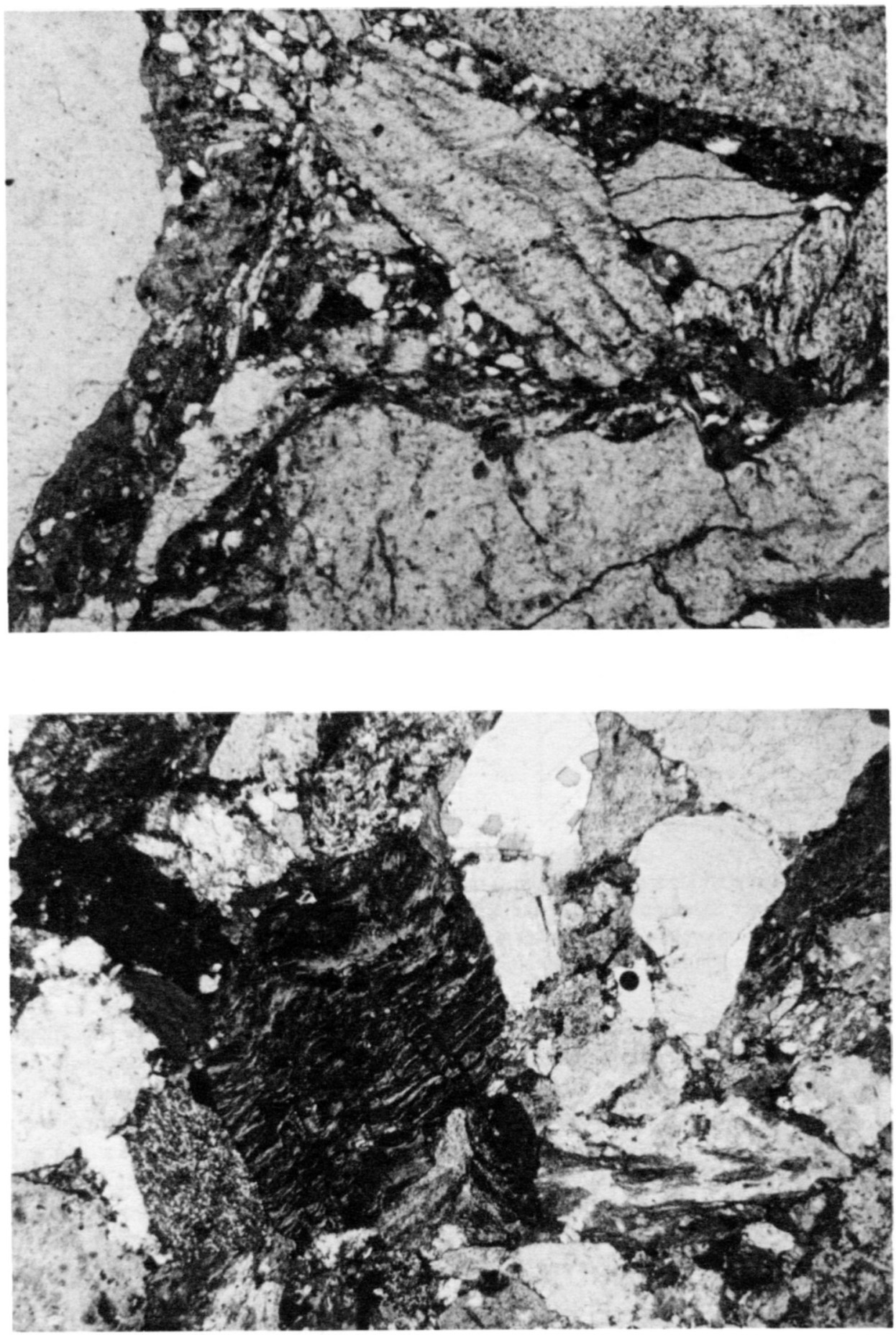

Fig. 4. Photomicrographs of conglomerate of the Silurian Simpsons Field Formation showing clasts with two pre-depositional cleavages. Field of view is $6 \mathrm{~mm}$ long.

volcanic rocks mainly consist of spherulitic, flow-banded rhyolite, but tuff and porphyritic rhyolite flows are also present where the unit thickens to the south.

A unit of massive, thickly bedded, olive-grey, reddishgrey to brownish-grey, clean, slightly calcareous sandstone with minor lenses of fine grained conglomerate, which conformably overlies felsic volcanic rocks of the Benjamin Formation, is assigned to the Greys Gulch Formation. Ripples and load casts were noted in one location. An Early Devonian age was obtained from the top of this formation (Helmstaedt, 1971) just east of First Portage Lake. As in the western ex- tension of the Nigadoo River Syncline, the Greys Gulch Formation (Fig. 3) is conformably overlain by mafic and felsic volcanic rocks of the Tobique Group.

\section{Tobique Group}

The Tobique Group mainly consists of mafic flows that are characteristically massive, strongly magnetic and only rarely amydaloidal or porphyritic. They conformably overlie the Greys Gulch Formation in a north-northeast-trending band near Second Portage Lake. Minor greyish-red, feldspar 
porphyritic rhyolite and lithic lapilli tuff overlie the mafic volcanic unit, and spherulitic rhyolite occurs in drill holes located near the base of the mafic volcanic unit. These mafic volcanic rocks also occur in the core of the east-northeast-trending syncline west of Portage Lakes.

\section{Intrusive Rocks}

Numerous felsic and mafic intrusions occur in the Portage Brook area and range in size from dikes to plutons 3 $\mathrm{km}$ across. Ordovician intrusions include the Popple Depot Granite, which is a fine to medium grained, equigranular biotite granite that intrudes the Chain of Rocks Formation; this granite has yielded a U-Pb zircon date of $474 \pm 4 \mathrm{Ma}$ (Gower, in press). At least two lithologies are present in the intrusion, both of which clearly show two structural fabrics. Two gabbroic bodies that intrude the Tetagouche Group are deformed and altered and, therefore, are also considered to be of Ordovician age.

Most of the other intrusions are generally undeformed and considered to be part of the Late Silurian-Early Devonian Mount Elizabeth Intrusive Complex. They include the Portage Brook troctolite and a series of associated gabbroic plutons, which were emplaced into Cambro-Ordovician rocks along a north-northwest trend, parallel to the Portage Brook Fault. This set of intrusions is marked by a prominent magnetic high suggesting that they are different units of the same complex. Based on textural evidence, Whalen (1993) inferred that these mafic intrusions are more or less contemporaneous with a peraluminous granite located south of the map area (Fig. 1). This granite has yielded a U-Pb monazite age of $418 \pm 1 \mathrm{Ma}$ (Bevier and Whalen, 1990), which approximately coincides with the Silurian/Devonian boundary (Tucker and McKerrow, 1995).

An orange to red, medium to coarse grained, equigranular, high-level alkali granite has intruded, and transformed to hornfels, clastic rocks of the Simpsons Field Formation in the southwestern corner of the map area. Typically the granite contains only one feldspar (K-feldspar) and is amphibole bearing (Whalen, 1993).

As first noted by Whalen (1993), Late Silurian/Early Devonian, high-level alkali granite in this area looks like the intrusive equivalent of the rhyolites that we assign to the Benjamin Formation. This conclusion is supported by geochemistry. Results from analyses of four felsic volcanic samples from the Benjamin Formation are shown in Table 1 and Figures 5 and 6. Also shown in Figures 5 and 6, for comparative purposes, are data reported by Whalen (1993) for the Late Silurian granite (NB-107, NB-291) and an aplite dike (NB-103) from the southwestern part of the map area and interpreted to be coeval with volcanic rocks of the Benjamin Formation. Rare-earth-element and multi-element profiles of the rhyolitic and granitic rocks are similar, supporting a genetic link. However, the volcanic rocks are slightly enriched in heavy-rare-earth-elements and have larger Eu anomalies than the granitic rocks, possibly reflecting fractionation processes near the top of the magma chamber. Sample SG95-417 is depleted in light-rare-earth-elements (LREE) possibly
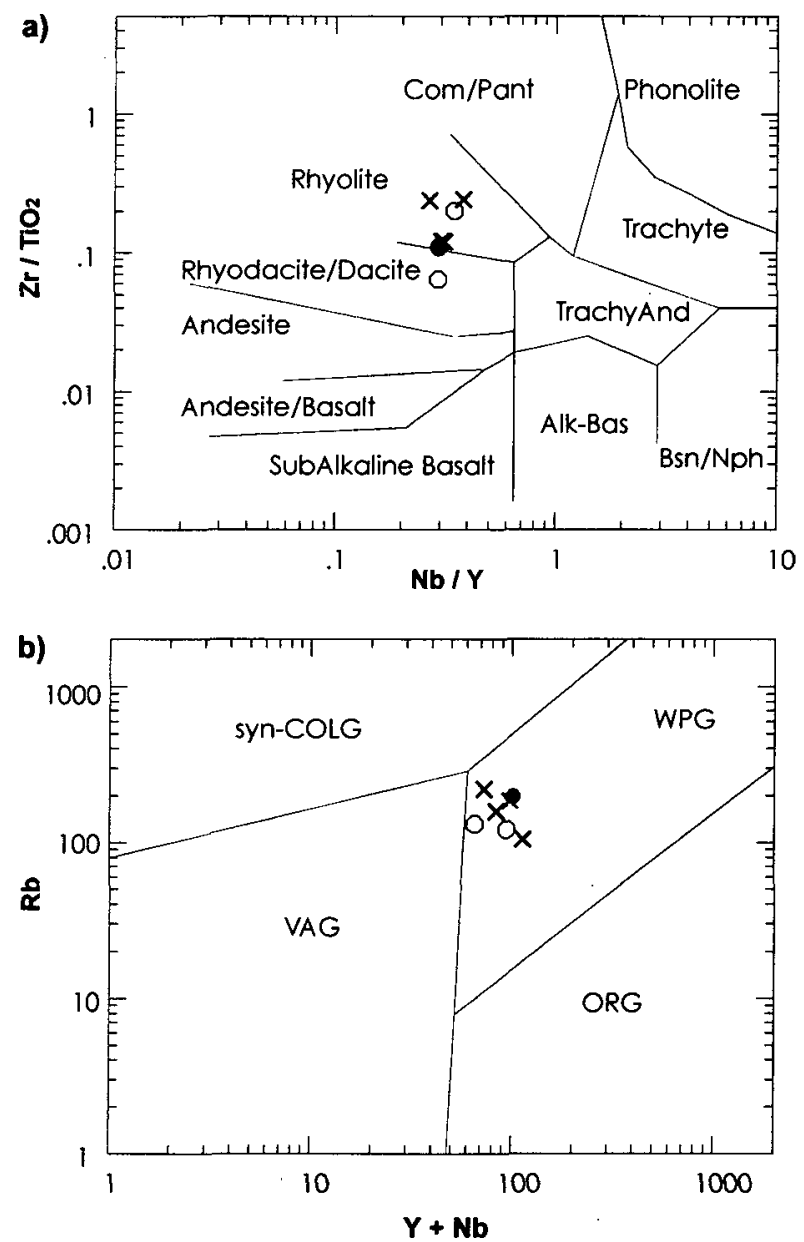

Fig. 5. (a) $\mathrm{Nb} / \mathrm{Y}$ versus $\mathrm{Zr} / \mathrm{TiO}_{2}$ discrimination diagram (field boundaries after Winchester and Floyd, 1977), and (b) Rb versus $\mathrm{Y}+\mathrm{Nb}$ discrimination diagram for granitic rocks (after Pearce et al., 1984). WPG = within-plate granite; syn-COLG = syncollisional granite; VAG $=$ volcanic arc granite; $O R G=$ oceanridge granite; $\mathrm{X}=$ felsic volcanic rocks, Benjamin Formation; $\mathrm{O}$ $=$ alkali-granite and $0=$ aplite from the southwestern part of the study area, after Whalen (1993).

reflecting alteration or, alternatively, fractionation of a LREErich accessory mineral. On the granite discrimination diagrams $(\mathrm{Y}+\mathrm{Nb}-\mathrm{Rb}$ and $\mathrm{Y}-\mathrm{Nb})$ of Pearce et al. (1984) both the granites and the rhyolites clearly have within-plate-granite signatures. This is consistent with results from other studies (Dostal et al., 1989, 1993), which indicate that the mafic and felsic volcanic rocks in the Chaleurs Bay Synclinorium have evolved in a within-plate-tectonic setting. This alkali granite yielded a U-Pb zircon age of $414+11 /-1 \mathrm{Ma}$ (Bevier, 1988).

\section{Structure}

Helmstaedt (1971) recognized three main phases of penetrative deformation in the Portage Brook area: an early stage of deformation associated with a penetrative fabric and macroscopic folding accompanied by differential movements along lithological contacts, a second phase associated with a shallowdipping crenulation cleavage, and a third phase resulting in a north-northwesterly plunging regional fold. Recently 


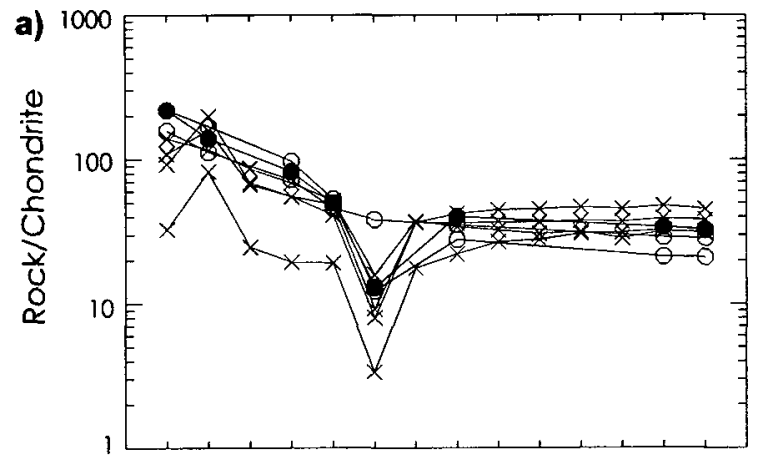

La CePr NdSm Eu GdTb Dy Ho Er Im Yb Lu

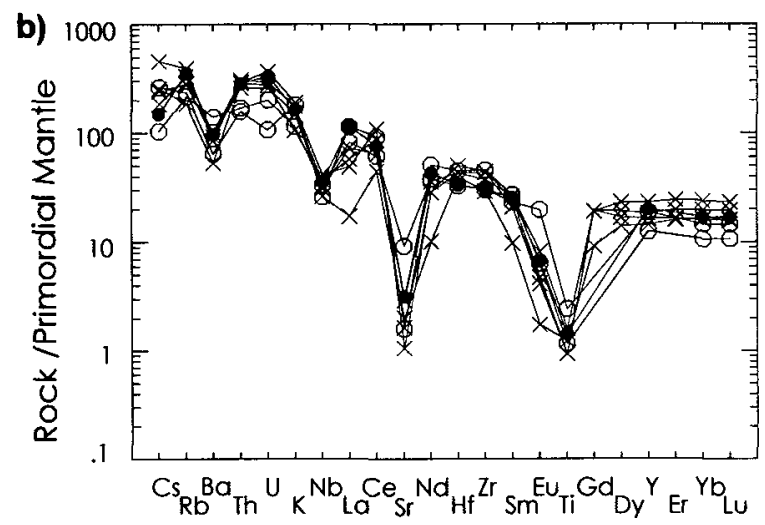

Fig. 6. (a) Chondrite-normalized rare-earth-element profiles and (b) averaged multi-element profiles of: Benjamin Formation felsic volcanic rocks $(\mathrm{X}) ; \mathrm{O}=$ alkaline granite and $\mathbf{O}=$ aplite from the southwestern part of the study area, after Whalen (1993). Normalizing values after Nakamura (1974).

de Roo and van Staal (1994) recognized at least four tectonic events $\left(D_{1}\right.$ to $\left.D_{4}\right)$ and divided the Bathurst Mining Camp into steep belts dominated by $D_{1}$ and $D_{2}$ structures and flat belts characterized by a pervasive flat lying cleavage ( $S_{3}$, described as $S_{2}$ by Hemstaedt, 1971).

Generally, the main fabric is a closely spaced, composite foliation $\left(\mathrm{S}_{1} / \mathrm{S}_{2}\right)$ defined by differentiated layering. Only in some areas, such as in the hinge of large-scale early folds (Fig. 7), are the two early fabrics clearly distinguished. The distribution of lithological units in the map area is largely controlled by tight, overturned early folds and by associated thrust faults. The Miramichi Group forms the core of a major northeast to north-south striking anticlinorium (Upsalquitch Lake Anticline, Helmstaedt, 1971) that is overturned to the southeast. On the northern limb of this fold, volcanic rocks of the Tetagouche Group conformably overlie the Miramichi Group and are repeated to the north in the core of another anticline that plunges to the east-northeast. A thrust fault occurs along the overturned limb of the northern anticline and progressively truncates Tetagouche Group stratigraphy to the south. An interpreted thrust along the northwest limb of the syncline in the Upsalquitch Lake area (Fig. 2) progressively truncates the Nepisiguit Falls Formation to the south and may be responsible for the absence of the Patrick Brook Formation in this area.
A north-northwest to north-northeast striking, shallowdipping, penetrative $S_{3}$ crenulation cleavage (described as the second phase of deformation by Helmsteadt, 1971) is well developed. Although this deformation does not appear to have had a major affect on the regional map pattern, it probably served to re-orient the regional fold axes to their present shallow-dipping attitudes.

The early composite cleavage changes from an overall northeast trend in the area between Upsalquitch Lake and the Restigouche Deposit to a north-south orientation east of the Portage Brook Fault. This reorientation is caused by a large-scale $\mathrm{F}_{4}$ fold trending north-northwest (Fig. 2). A regionally penetrative $\mathrm{S}_{4}$ spaced cleavage, typically strikes north-northwest and is axial planar to the major regional $\mathrm{F}_{4}$ fold and numerous upright, open minor folds (described as the third deformation by Helmstaedt, 1971).

Immediately west of the Portage Brook Fault, the SiluroDevonian section dips consistently to the northwest and shows little evidence of deformation. The sequence is upthrown and deformed by folds trending east-northeast, north of Second Portage Lake Fault.

\section{Discussion}

The clastic rocks in the lower part of the Portage Brook section (5 in Fig. 3) lithologically resemble the Simpsons Field Formation found at the base of the section in the southern part of the Nigadoo River Syncline ( 3 in Fig. 5). The upper part of the Portage Brook section (red beds overlain by mafic volcanic rocks) also resembles the section in the southern part of the Nigadoo River Syncline. However, in contrast to the predominantly fine grained sedimentary assemblage in the middle part of Chaleurs Group in the Nigadoo River Syncline, the middle part of the Portage Brook section contains a significant volcanic component. Lithologically the middle part of the section west of the Portage Brook Fault bears greatest resemblance to the section in the Jacquet River Syncline (4 in Fig. 3), suggesting that similar tectonic and physiographic conditions prevailed in both areas. This is not surprising considering that these areas occupied the same structural position relative to the Elmtree and Miramichi blocks. If the dextral movement (approximately $60 \mathrm{~km}$ ) proposed by van Staal et al. (1990) and Winchester et al. (1992) for displacement along the RBMF is removed, these areas are located in close proximity.

The recognition of Chaleurs Group rocks in the Portage Brook area has implications for the timing of deformation in the Bathurst Mining Camp. Although the presence of two pre-depositional cleavages in Ordovician pebbles in this area has been known for some time (Helmstaedt, 1971), the conglomerates previously were assumed to be younger (Early Devonian) than the conglomerates to the north in the Nigadoo River Syncline. The recognition that the conglomerates containing polydeformed pebbles can be correlated with the middle Wenlockian to upper Ludlovian Simpsons Field Formation of the Chaleurs Group implies that $\mathrm{D}_{2}$ deformation occurred in the Early Silurian, prior to deposition of this unit. 


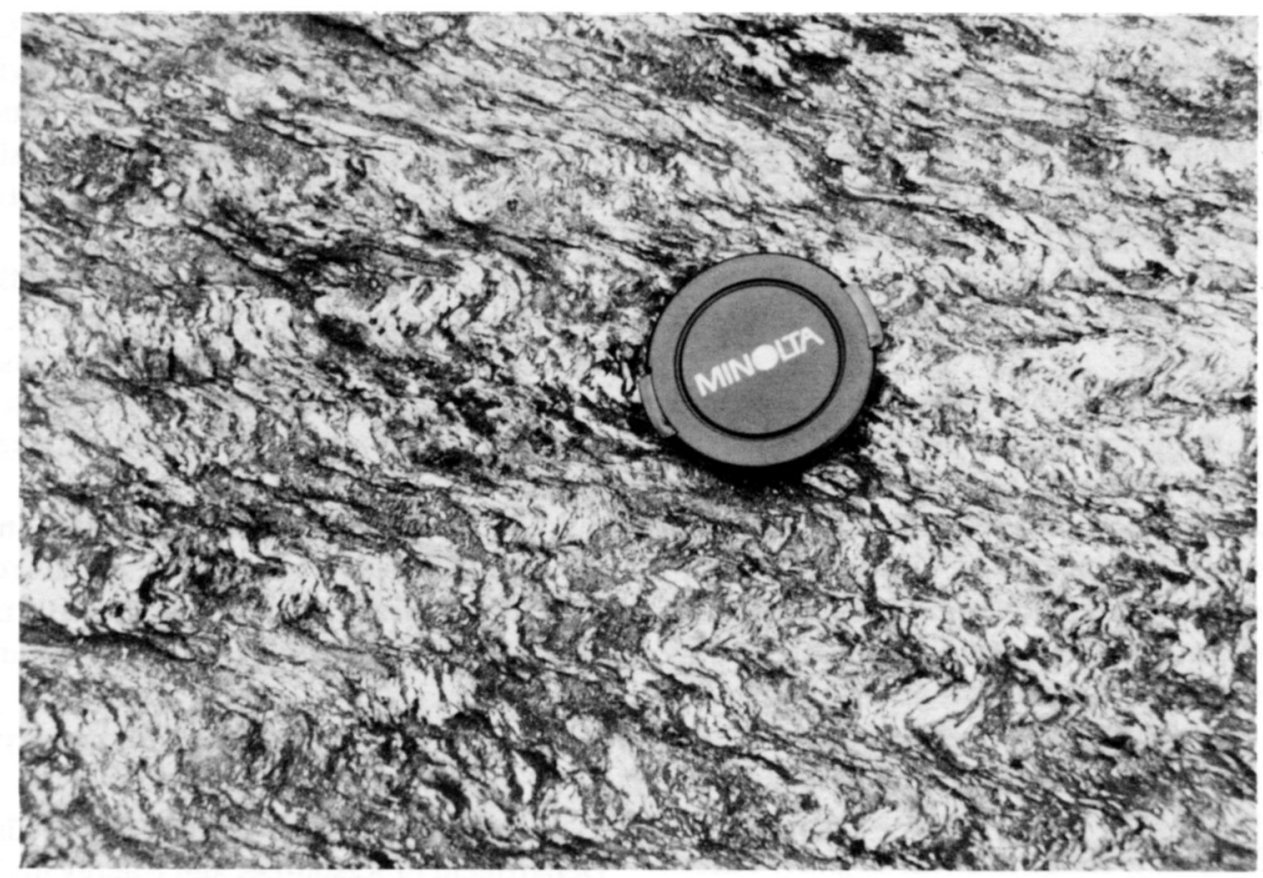

Fig. 7. Outcrop of Nepisiquit Falls Formation showing a well developed north-south trending $S_{2}$ crenulation cleavage overprinting an $S_{1}$ schistosity. The outcrop is located approximately $100 \mathrm{~m}$ north of an undeformed troctolite body of the Mount Elizabeth Intrusive Complex.

This relationship is supported by the intrusive relationships east of the Portage Brook Fault. Folds and thrusts in the Ordovician rocks of the Bathurst Mining Camp are truncated by a series of mafic intrusions considered to be contemporaneous with the Late Silurian/Early Devonian (418 $\pm 1 \mathrm{Ma}$ ) peraluminous granite of the Mount Elizabeth Intrusive Complex. This apparent truncation of the "steep belt" was also noted by de Roo and van Staal (1994). The mafic intrusions are considered to have a similar age or be older because: (1) rocks of hybrid composition and textural evidence suggest magma-mixing (Whalen, 1993); (2) felsic dikes cut mafic rock but no mafic dikes have been observed cutting felsic rock (Whalen, 1993); and (3) the emplacement of mafic intrusions in the Portage Brook and Goodwin Lake areas appears to have been controlled by a structure that has been sealed by the peraluminous granite (Fig. 1). Figure 7 clearly shows a well developed $S_{2}$ crenulation cleavage trending north-south overprinting $S_{1}$ schistosity. Although the $S_{2}$ cleavage strikes into troctolite of the Mount Elizabeth Intrusive Complex, located approximately $100 \mathrm{~m}$ to the south, there is no evidence of deformation in the intrusion in this area or elsewhere within the Mount Elizabeth Intrusive Complex, suggesting that $\mathrm{D}_{\mathbf{2}}$ deformation predated Late Silurian/Early Devonian plutonism.

The four, or perhaps five, stages of deformation manifested in the Bathurst Mining Camp are currently considered to have developed progressively in response to closing of a back-arc basin followed by collision of the Gander margin of Gondwana with Laurentia. de Roo and van Staal (1994) proposed the following sequence of events: Late Ordovician subduction, associated with closure of the back arc basin $\left(D_{1}\right)$; Late Silurian sinistral transpression resulting from oblique continental collision $\left(\mathrm{D}_{2}\right)$; Early Devonian exten- sional collapse $\left(\mathrm{D}_{3}\right)$; and Middle Devonian dextral transpression (D4). However the relationships described above cast doubt about the timing of the $D_{2}$ and $D_{3}$ events. Therefore we propose a different chronology as described below.

$D_{1}$ and $D_{2}$ are interpreted to represent subduction and obduction, respectively, of a back-arc basin in Late Ordovician to Early Silurian time. In previous interpretations such as those of Skinner (1956 a,b), Helmstaedt (1971) and Fyffe (1982), early folds in the Bathurst Mining Camp were considered to be a manifestation of the Middle to Late Ordovician Taconian Orogeny whereas later large-scale folds in the Camp and structures in the Silurian-Devonian rocks were attributed to the Acadian Orogeny. Although Helmstaedt (1971) tentatively assigned the conglomerates west of the Portage Lake Fault to the Devonian, he reasoned that no unconformity is present between the Late Silurian and Early Devonian and thus considered the first two phases of deformation in the Bathurst Camp $\left(D_{1}\right.$ and $\left.D_{2}\right)$ to be pre-Late Silurian events (i.e., interpreted to be a manifestation of the Taconian Orogeny). However, the Taconian Orogeny is characteristic of the Laurentian margin, not the Gondwanan margin of which the Bathurst Camp is part.

Recent work, however, has shown that the early deformation in the Tetagouche Group is unrelated to the Taconian Orogeny but rather occurred in the Late Ordovician to Early Silurian during closure of a back-arc basin located near the Gondwanan margin (van Staal, 1994), and may form part of the Salinic orogenic belt exposed from western Europe to southern New England (Stewart et al., 1995).

The Late Silurian age suggested for the $\mathrm{D}_{2}$ deformation is largely based on microstructural evidence indicating that porphyroblasts in the contact aureole of the Late Silurian/Early Devonian Mount Elizabeth Intrusive Complex 
are generally syntectonic with $\mathrm{D}_{2}$ (de Roo and van Staal, 1994). However, these relationships are contradicted by an Early Silurian ( 430) age for $\mathrm{D}_{2}$ deformation from $\mathrm{Ar}^{40}$. $\mathrm{Ar}^{39}$ dating of two samples of $\mathrm{S}_{2}$ muscovite from the vicinity of the Mount Elizabeth Intrusive Complex (de Roo and van Staal, 1994) and by the relationships described above. Therefore, it is possible that the microstructures observed in the porphyroblasts are related to a later stage of deformation.

Thus, it seems likely that the $\mathrm{D}_{2}$ deformation occurred in the Early Silurian, and was closely associated with the Late Ordovician to Early Silurian $D_{1}$ deformational event.

Following the earliest deformations, uplift accompanied by volcanism in the late Wenlockian to Ludlovian is indicated by deposition of conglomerate and sandstone of the Simpsons Field Formation and subaerial volcanic rocks of the Bryant Point and Benjamin formations. Geochemistry indicates that Late Silurian volcanism and plutonism took place in a within-plate-tectonic setting, and Dostal et al. (1989) have suggested that it occurred as a result of intracontinental rifting in a sinistral shear regime. Alternatively, van Staal and Fyffe (1991) proposed that the Silurian-Devonian bimodal magmatism in this area resulted from delamination of the down-going Gondwanan plate following collision. The latter explanation is preferred considering the overall compressive tectonic setting of the area at the time and the widespread occurrence of Late SilurianDevonian igneous rocks. Furthermore, the magmatism and volcanism show no obvious spatial relationship to promontory-reentrant geometry or faults, and crosses all tectonostatigraphic boundaries (van Staal and de Roo, 1995). It seems reasonable that extensional collapse associated with $D_{3}$ deformation was synchronous with this period of uplift, delamination and plutonism, perhaps coinciding with deposition of the Simpsons Field Formation.

Two deformations have been documented in the SiluroDevonian rocks of the Nigadoo River Syncline. Upright eastnortheast-trending folds $\left(F_{1}\right)$ are transected by a northeasterly striking cleavage that is axial planar to rarely observed $F_{2}$ folds (van Staal, 1988). The east-northeast trending folds north of the Second Portage Lake Fault are of the same orientation and style as the earliest stage of folding recognized in the Nigadoo River Syncline. In the Portage Brook area this stage of folding has clearly affected Lower Devonian volcanic rocks of the Tobique Group. Therefore, both stages of deformation in the the Chaleurs Bay Synclinorium are likely coeval with late stage ( $D_{4}$ and perhaps $\left.D_{5}\right)$ deformation in the Bathurst Mining Camp.

\section{Conclusions}

Chaleurs Group rocks have been recognized along the western margin of the Miramichi Anticlinorium in the Portage Brook area. The stratigraphic section in this area resembles that in the Jacquet River Syncline, indicating that these two areas have undergone similar tectonic and depositional histories.
Two pre-depositional cleavages in Ordovician pebbles of the upper Wenlockian to upper Ludlovian Simpsons Field Formation and the truncation of $D_{2}$ structures by Late Silurian/Early Devonian intrusions suggest that $D_{2}$ deformation in the Bathurst Mining Camp occurred prior to the Late Silurian.

Uplift and magmatism occurred in the Late Silurian as shown by the deposition of conglomerate and subaerial volcanic rocks and the intrusion of numerous plutons; they were probably synchronous with or immediately preceded extensional collapse ( $D_{3}$ deformation) in the Bathurst Mining Camp.

The two deformations recognized in the Chaleurs Bay Synclinorium have affected Devonian rocks and therefore are both considered to be coeval with the latest stages of deformation ( $\mathrm{D}_{4}$ and/or $\mathrm{D}_{5}$ ) in the Bathurst Mining Camp.

\section{ACKNowledgements}

The mapping was carried out by the New Brunswick Department of Resources and Energy under the federal-provincial EXTECH II program. Alice Walker is thanked for her mapping assistance and Phil Evans for drafting Figure 2. Analytical Services were carried out by XRAL Laboratories in Don Mills, Ontario. We also thank C.R. van Staal and Les R. Fyffe for reviews of the manuscript.

Alcock, F.J. 1935. Geology of Chaleurs Bay region. Geological Survey of Canada, Memoir 183, 146 p.

BEVIER, M.L. 1988. U-Pb geochronologic studies of igneous rocks in New Brunswick. In Thirteenth Annual Review of Activities. Compiled and edited by S.A. Abbott. Mineral and Energy Division, Department of Natural Resources and Energy, New Brunswick, Information Circular 88-2, pp. 134140.

Bevier, M.L. and Whalen, J.B. 1990. Tectonic significance of Silurian magmatism in the Canadian Appalachians. Geology, 18, pp. 411-414.

Bourque, P.-A. 1987. Silurian stratigraphic and facies, Port-Daniel/ Gascons and Black-Cape areas, southern Gaspé Peninsula, Québec. Edited by D.C. Roy. Geological Society of America, Centennial Field Guide-Northeastern Section, 5, pp. 379384.

Bourque, P.-A., Brisebois, D., and Malo, M. 1995. Gaspé Belt. In Geology of the Appalachian-Caledonian Orogen in Canada and Greenland, Chapter 4. Edited by H. Williams. Geological Survey of Canada, Geology of Canada, No. 6, pp. 316 351 (also Geological Society of America, The Geology of North America, v. F-1).

DE Roo, J.A. and van StaAl, C.R. 1994. Transpression and extensional collapse: Steep belts and flat belts in the Appalachian central mobile belt, northern New Brunswick, Canada. Geological Society of American Bulletin, 106, pp. 541-552.

Dostal, J., Wilson, R.A., and KepPIE, J.D. 1989. Geochemistry of Siluro-Devonian Tobique volcanic belt in northern and central New Brunswick(Canada): tectonic implications. Canadian Journal of Earth Sciences, 26, pp. 1282-1296.

Dostal, J., Laurent, R., and Keppie, J.D. 1993. Late SilurianEarly Devonian rifting during dextral transpression in the southern Gaspé Peninsula (Quebec): petrogenesis of volca- 
nic rocks. Canadian Journal of Earth Sciences, 30, pp. $2283-$ 2294.

FyFFE, L.R, 1982. Taconian and Acadian structural trends in central and northern New Brunswick. Edited by P. St-Julien and J. Béland. Geological Association of Canada, Special Paper 24, pp. 117-130.

FyfFe, L.R. and FrICKER, A. 1987. Tectonostratigraphic Terrane Analysis of New Brunswick. Maritime Sediments and Atlantic Geology, 23, pp. 113-122.

FyFFE, L.R. and NoBlE, J.P.A. 1985. Stratigraphy and structure of the Ordovician, Silurian and Devonian of northern New Brunswick. In Field Guide, Excursion 4. Geological Association of Canada, Mineralogical Association of Canada, Fredericton, New Brunswick, 2, pp. 1-56.

GOWER, S.J. In press. Geology, lithogeochemistry and mineral occurrences in the Portage Brook Area, northwestern Bathurst Mining Camp. In Current Research 1995. Compiled and edited by Barbara Carroll. New Brunswick Department of Natural Resources and Energy, Minerals and Energy Division.

Greiner, H.R. 1967. Siluro-Devonian relationships, Charlo map area, New Brunswick. In International Symposium on the Devonian System. Edited by D.H. Oswald. Alberta Society of Petroleum Geologists, Calgary, Alberta, 2, pp. 973-979.

Helmstaedt, H. 1971. Structural geology of Portage Lakes area, Bathurst Newcastle District, New Brunswick. Geological Survey of Canada, Paper 70-28, 52 p.

IRRINKI, R.R. 1990. Geology of the Charlo area; Restigouche County, New Brunswick. New Brunswick Department of Natural Resources and Energy, Mineral Resources, Report of Investigation 24, $118 \mathrm{p}$.

Malo, M. and Bourque, P.A. 1993. Timing of the deformation events from Late Ordovician to Mid-Devonian in the Gaspé Peninsula. In The Orogeny: Recent Studies in New England, Maritime Canada, and the Autochthonous Foreland: Boulder, Colorado. Edited by D.C. Roy and J.W. Skedan. Geological Society of America, Special Paper 275.

Nakamura, N. 1974. Determination of REE, Ba, Fe, $\mathrm{Mg}, \mathrm{Na}, \mathrm{K}$ in carbonaceous and ordinary chondrites. Geochemica et Cosmochimica Acta, 38, pp. 290-300.

NoBlE, J.P.A. 1976. Silurian stratigraphy and paleogeography, Point Verte area, New Brunswick, Canada. Canadian Journal of Earth Sciences, 13, pp. 537-546.

Pearce, J.A., Harris, N.B.W., and Tindle, A.G. 1984. Trace element discrimination diagrams for the tectonic interpretation of granitic rocks. Journal of Petrology, 25, pp. 956-983.

Rodgers, J. 1970. The Tectonics of the Appalachians. John Wiley and Sons, Inc., New York, 271 p.

SkINNER, R. 1956. Tetagouche Lakes. Geological Survey of Canada, Paper 55-32.

Steward, D.B., Unger, J.D., and Hutchinson, D.R. 1995. Silurian tectonic history of Penobscot Bay region, Maine. Atlantic Geology, 31, pp. 67-79.
TUCKer, R.D. and McKerrow, W.S. 1995. Early Paleozoic chronology: a review in light of new U-Pb zircon ages from Newfoundland and Britain. Canadian Journal of Earth Science, 32, pp. 368-379.

van StaAl, C.R. 1988. A new look at the structural history of the Silurian Chaleurs Group in northern New Brunswick: evidence for a complex polyphase deformation history and dextral shear associated with $\mathrm{F}_{3}$ folding. Maritime Sediments and Atlantic Geology, 24, pp. 216-217.

---- 1994. Brunswick subduction complex in the Canadian Appalachians: record of the Late Ordovician to Late Silurian collision between Laurentia and the Gander margin of Avalon. Tectonics, 13, pp. 946-962.

VAN STAAL, C.R. and DE Roo, J.A. 1995. Mid-Paleozoic tectonic evolution of the Appalachian Central Mobile belt in northern New Brunswick, Canada: Collision, extensional collapse and dextral transpression. In Current Perspectives in the Appalachian-Caledonian Orogen. Edited by J.P. Hibbard, C.R. van Staal and P.A. Cawood. Geological Association of Canada, Special Paper 41, pp. 367-389.

van StaAl, C. and FyfFe, L.R. 1991. Dunnage and Gander zones, New Brunswick: Canadian Appalachian Region. New Brunswick Department of Natural Resources and Energy, Mineral Resources, Geoscience Report 91-2, 39 p.

van StaAl, C.R., Ravenhurst, C., Winchester, J.A., Roddick, J.C., and Langton, J.P. 1990. Post Taconic blueschist suture in the northern Appalachians of northern New Brunswick, Canada. Geology, 18, pp. 1073-1077.

WALKER, J.A. and MCCUTCHEON, S.R. 1990. Geology of Upsalquitch Forks map area $(21 \mathrm{O} / 10)$. New Brunswick Department of Natural Resources and Energy, Mineral Resources, Map Plate 90-24.

-...- 1995. Siluro-Devonian stratigraphy of the Chaleurs Bay Synclinorium, northern New Brunswick. In Current Research 1994. Compiled and edited by S.A.A. Merlini. New Brunswick Department of Natural Resources and Energy, Minerals and Energy Division, Miscellaneous Report 18, pp. 225-244.

Whalen, J.B. 1993. Geology, petrography and geochemistry of Appalachian granites in New Brunswick and Gaspésie, Quebec. Geological Survey of Canada Bulletin, 426, $124 \mathrm{p}$.

WinCHESTER, J.A. and Floyd, P.A. 1977. Geochemical discrimination of different magma series and their differentiation products using immobile elements. Chemical Geology, 20, pp. 325-343.

Winchester, J.A., van Staal, C.R., and Langton, J.P. 1992. The Ordovician volcanics of the Elmtree-Belledune inlier and their relationship to volcanics of the northern Miramichi Highlands, New Brunswick. Canadian Journal of Earth Sciences, 29, pp. 1430-1447. 